\title{
Impacts of gravel-bed rivers transformation on fluvial ecosystems and human society: Examples from the Czech flysch Carpathians
}

\author{
Václav Škarpich ${ }^{1, *}$, Miroslav Kubín ${ }^{2}$, Tomáš Galia ${ }^{1}$, Stanislav Ruman ${ }^{1}$, and Jan Hradecký ${ }^{1}$ \\ ${ }^{1}$ Department of Physical Geography and Geoecology, Faculty of Science, University of Ostrava, \\ Chittussiho 10, 71000 Ostrava, Czech Republic \\ ${ }^{2}$ Protected Landscape Area Administration Beskydy, Nádražní 3675661 Rožnov pod Radhoštěm, \\ Czech Republic
}

\begin{abstract}
In the last centuries, gravel-bed rivers in developed countries have undergone rapid changes in channel morphology. The most serious problems include channel transformation related to progressive channel narrowing, incision or bed sediment coarsening. The main reasons for transformations were connected to the human interventions, which affected water and sediment fluxes in the basins. This paper summarizes contemporary research activities focused on these negative effects of channel transformations in the Czech flysch Carpathian rivers (the Morávka, the Olše and the Ostravice draining the highest mountainous areas of the Beskydy Mts). As the result of channel transformations, progressive changes in fluvial ecosystem were observed. The initial phytosociological survey demonstrates a higher biodiversity in the floodplain along the preserved multi-thread river channel than along the deeply incised channel in the Morávka River basin. Our observations of aquatic communities demonstrated that the channel transformation connected with incision and coarsening of bed sediments negatively affected fish or lamprey populations in the studied rivers. Regulation, damming and incision of channels caused changes of hydrological regime linked with gradual drying of floodplain. Additionally, a large set of hydraulic structures, bridges or weirs were affected by undercutting and progressive destruction in the Ostravice, Olše and Morávka River basins, which is assigned to increased transport capacity of regulated channels together with decreased sediment supply from mountainous parts.
\end{abstract}

\section{Introduction}

Gravel-bed rivers are defined as channel reaches with coarse sediment material on bed and banks and typically with large discharge variation, which affects sediment material movement in river network $[1,2]$. Their occurrence is characteristic for montane and upland valley and mountain foreland area [3]. During the 20th century, the most serious problems of gravel-bed rivers transformation were widely studied around the globe $[4,5$,

\footnotetext{
* Corresponding author: vaclav.skarpich@osu.cz
} 
6]. The researches focused on the identification of channel pattern changes, which were accompanied by progressive channel narrowing, river bed incision or bed sediment coarsening $[4,5,6]$. The main reasons for these changes were related to the sediment movement and impediments (buffers, barriers and blankets) to sediment movement in the fluvial system by so-called disconnectivities [7].

A similar pattern of channel changes was also recorded in the rivers draining the Czech part of flysch Carpathians $[8,9,10,11]$. This paper presents channel transformations in a wider context of ecosystem changes and water resources structures. A number of detrimental feedback effects of transformation of the Czech Carpathian rivers have been identified, e.g. decreasing biodiversity, destruction of fish and lamprey habitat, landscape drying or destruction of man-made constructions (as weirs or bridges).

\section{Channel transformations and their effect on riverine ecosystems in the Czech Carpathian rivers}

Transformations of rivers draining the Czech part of Carpathian were studied in the Ostravice, Morávka $[8,9,10]$ and Olše [11] River basins. The contemporary state of rivers in the Czech Carpathians has been particularly affected by human impact starting at the beginning of the 16th century during the so-called Wallachian colonisation of the mountainous area. Extensive deforestation to clear pastureland and supply the demand for wood disrupted the original state of channels. The deforestation and probably effect of Little Ice Age intensified sediment supply to the river network and subsequently development of multi-thread channel reaches, which had been developing from the end of the Last Glacial period [9]. The change in basin management related to the change in human lifestyles from the beginning of the 20th century brought new afforestation and thus an initiation of deficit in sediment supply for multi-thread reaches. Industrial development related to increased demands for large amounts of water (construction of valley dams, weirs), which caused the acceleration of the above-mentioned processes and the blockage of sediment transport. In result, channels were transformed from originally multi-thread river pattern with intensive sediment transport to single-thread river pattern often incised into the bedrock $[8,9,10,11]$.

Effect of channel transformation on riverine plant ecosystems was studied in the Morávka River basin [12]. The research was conducted with phytosociological survey of plant species composition from phytosociological relevés in the transversal profiles in the floodplain. They were conducted in the floodplain with (i) the single-thread bedrockincised channel and (ii) the preserved multi-thread channel. The Shannon-Wiener [13] and Simpson's [14] indices of biodiversity for the analysis of species distribution was evaluated. In the context of the importance of vegetation response to channel-floodplain conditions, the following environmental variables were selected as response variables for the analysis: phytosociological relevé distance from the main channel with flowing water, and relative elevation of a phytosociological relevé from the water level in the channel. The channel effect on the riparian vegetation conditions was evaluated by using multivariate data analysis of detrended correspondence analysis (DCA) and redundancy analysis (RDA).

The results showed that different plant habitat conditions occur in the incised channel reach and in the multi-thread channel reach [12]. The analysis of the Shannon-Wiener and Simpson's indices demonstrated a larger variety of habitat conditions in the floodplain area along the multi-thread river channel (see fig. 1). Multivariate analysis confirmed that incision processes of channel cause a more rapid change in the plant community composition with increasing distance from the main channel. This suggests that groundwater conditions could be affected by the river incision through the gradual relative sinking of water level in the river channel - relative to the floodplain level [12]. 

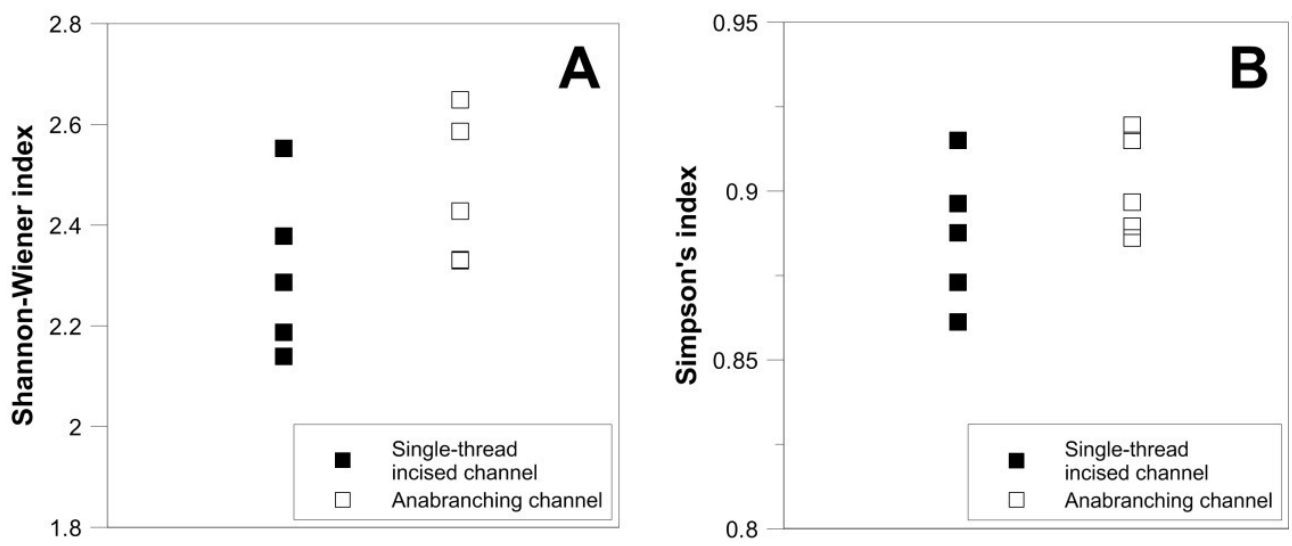

Fig. 1. A - Shannon-Wiener index and B - Simpson's index of phytosociological relevés in the study area of the Morávka River floodplain (reprinted from [12]).

In the last several decades, the flysch Czech Carpathian rivers showed changes of hydrological conditions. Originally, they were characterised by high discharge variation, e.g. for the Ostravice River it was approximately 1:2,000 between minimal and maximal discharges and for the Morávka River 1:4,000 [15]. Constructions of the Šance (built on the Ostravice River in years 1964-1969), the Morávka (built on the Morávka River in years 1961-1967) valley dams and partially the Morávka-Žermanice Canal (in the Morávka River basin) which diverts the water flow into the neighbouring Lučina River basin, caused the decrease in the frequency and magnitude of flood discharges (see fig. 2B). Similarly, the analysis of groundwater detected hydrological conditions changes of the floodplain which is gradually drying out in the Morávka River basin (see fig. 2A) [12].
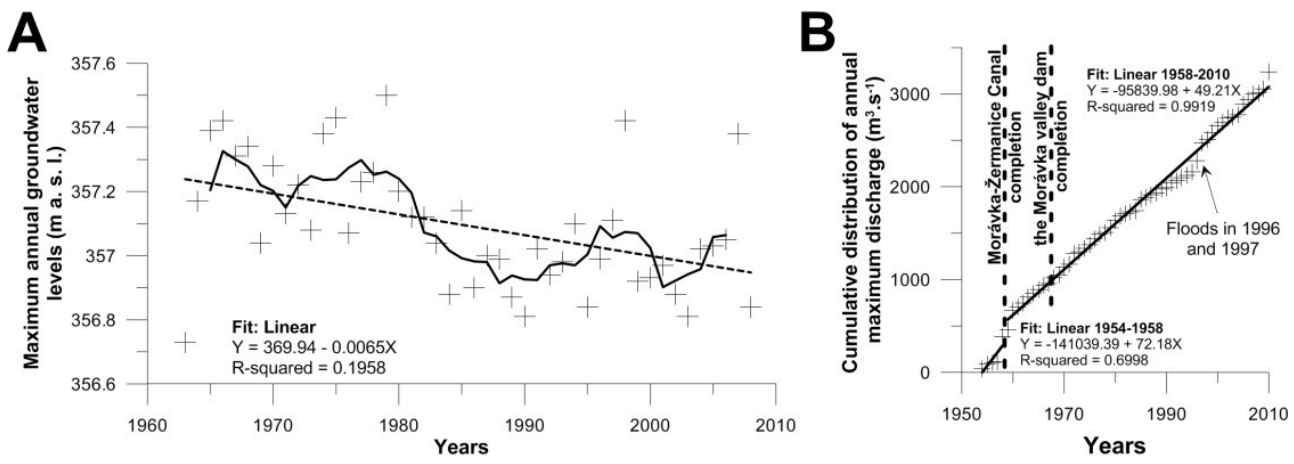

Fig. 2. A - Maximum annual groundwater levels in the years 1963-2008 at the VO 0096 - Nižní Lhoty drill well gauging station, cross symbols $(+)=$ maximum annual groundwater levels, solid line $=$ five point running mean, dashed line $=$ linear trend; $\mathrm{B}-$ Cumulative distribution of annual maximum discharge of the Morávka River at the Raškovice gauging station; cross symbols $(+)=$ cumulative distribution of annual maximum discharge (reprinted from [9, 12]; data source: Czech Hydrometeorological Institute).

\section{Fish and lamprey communities affected by channel transformation and related hungry water effect}

The channel transformations of the gravel-bed rivers within Czech part of Carpathians resulted in changes of flow hydraulics and it brought a new set of boundary conditions for erosion, transport and deposition processes $[10,11]$. Generally, increased flow velocity in 
transformed channels and hungry water effect related with coarsening of bed sediments of the studied rivers affected habitat for fish communities [16].

For example, Brook lamprey (Lampetra planeri), European bullhead (Cottus gobio) and Alpine bullhead (Cottus poecilopus) belong to protected species and they are listed in the Red List of threatened species of vertebrates of the Czech Republic [17]. Brown trout (Salmo trutta) represents a typical fish for Czech freshwaters and it is from the fishing industry focus economically important fish. The young larvae of Brook lampreys require river reaches with slow running flow and clay-sand bed substrate (with depth about $30 \mathrm{~cm}$ ) [18]. In contrast, adult Brook lampreys (like as Brown trouts) spawn in shallow fast running flow gravel close to the soft sediment bed reaches. The sand-bed substrate depth about 25 $\mathrm{cm}$ armoured gravels (with mean diameter of particle sizes from 5 to $20 \mathrm{~cm}$ ) and flow velocity to $0.3 \mathrm{~m} / \mathrm{s}$ is typical for bullheads [19]. In fact, complexity of habitats [20], variability of flow velocity of channel reaches [21] and sufficient refugium availability [22] is necessary for natural development of these fish lamprey species.

Based on the preliminary results of research, habitats of above mentioned fish and lamprey communities were highly degraded in some channel reaches of the Morávka River (see fig. 3). The main reasons for degradation of habitats were incision and narrowing of river reaches, absence of appropriate finer (clay and sand) bed deposits which are armouring gravel particles on bed and increased flow velocity in channels. Their number decreased in these reaches. In contrast, numerously- and age-balanced populations of lamprey and fish species were observed in river reaches with multi-thread channel pattern with gravel bed armoured by fine sediments and low flow velocities.
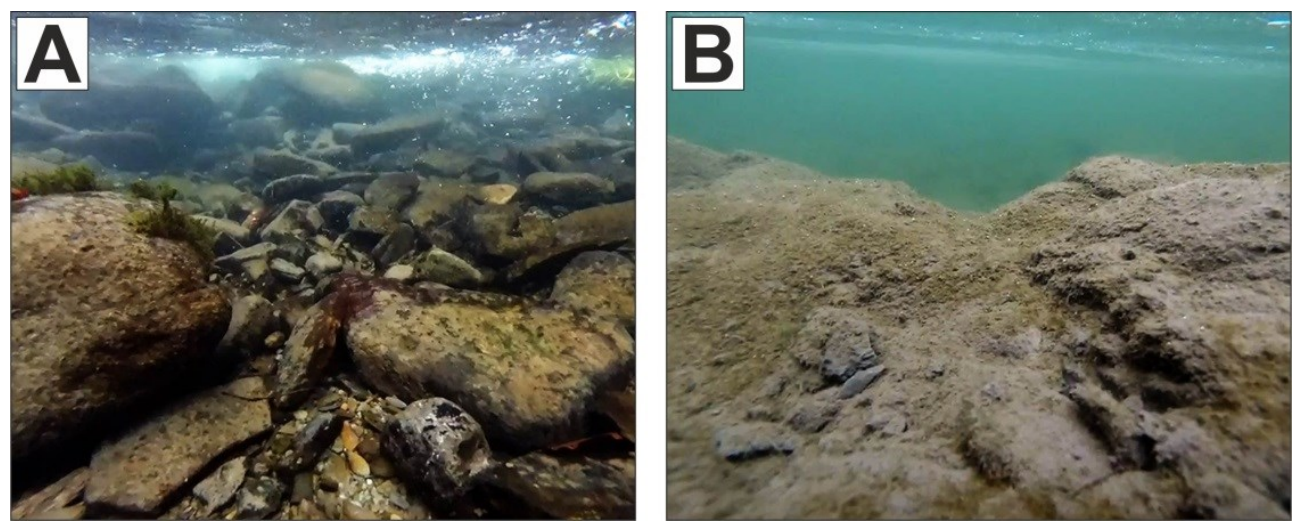

Fig. 3. A - Gravels and armouring fine sediments on the channel bed of the Ostravice River; B Channel bed of into the bedrock incised reach of the Morávka River (Photo: M. Kubín).

\section{Man-made river structures affected by erosion processes of Czech Carpathian rivers}

Negative effects of the transformation of gravel-bed rivers on human society (hydraulic structures) in Czech flysch Carpathians were visible in number of localities. Especially weir structures were affected by gradual incision and undercutting. In the Morávka River basin, the Vyšní Lhoty weir (at 11.38 r. km) built between 1953 and 1964 was gradually affected by undercutting and headward erosion. The Vyšní Lhoty weir has important function for society, when it improves water inflow into the adjacent Lučina River basin and Žermanice water reservoir and helps to decrease flood discharges downstream. The Žermanice water reservoir has important storage and water supply function for local industry. Firstly, a protective drop was made under the weir in 1969 , followed by a rock chute construction in 
1972 to prevent incision and undercutting [15]. In the year 2005, antierosion measures of local channel widening have been implemented below the Vyšní Lhoty weir, but problematic management connected with absence of bed sediment for support of close-tonatural processes of gravel-bed Morávka River caused total destruction of this antierosive measures. As the consequence, gradual incision of river reach $1-\mathrm{km}$ long below this measure took place during the flood in year 2010 [23]. Similarly, the Frýdek weir (at $1.25 \mathrm{r}$. $\mathrm{km})$ and the Konečný weir $(2.31 \mathrm{r}$. km) built in the lower river reach of the Morávka River were destroyed by floods from the reasons of headward erosion and undercutting (the first one was destroyed in 1949, the latter in the mid-1970s). Also, their destruction negatively affected originally multi-thread river channel pattern, which has been transformed into the single-thread channel incised $9 \mathrm{~m}$ below the original bed level since the 1970s [9]. Problematics of channel incision and its effect on man-made structures is not only a domain of weir structures. A large number of bridge constructions at crossing of the river channels in the Czech flysch Carpathians were destroyed or damaged by undercutting. For example, some bridges in the Ostravice River basin were repetively repaired several times (see fig 4). Similarly, bank stabilisation structures, as typical technical approach for river regulation, are very often damaged by lateral erosion processes.

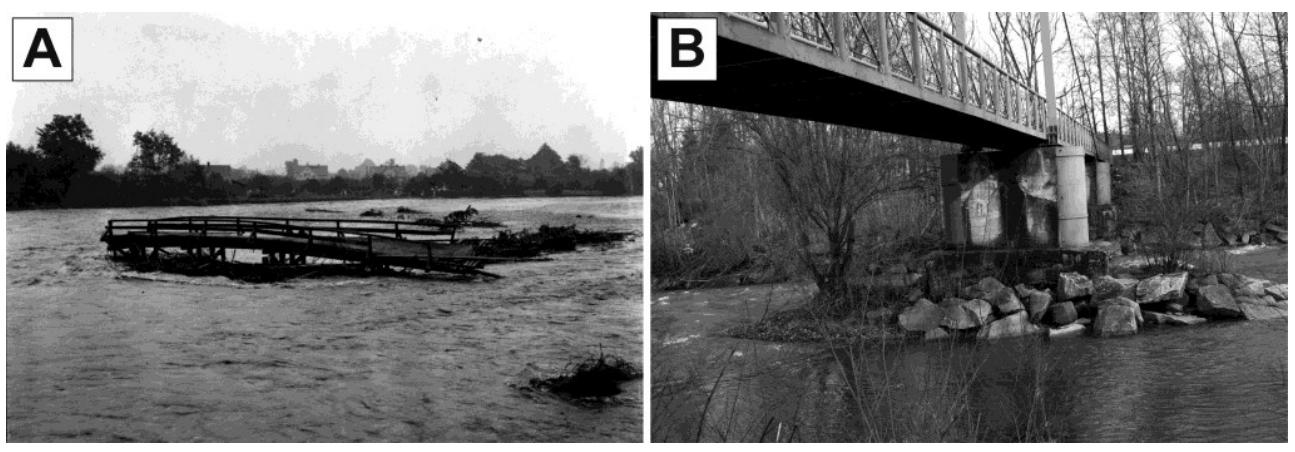

Fig. 4. A residue of wooden bridge crossing the Ostravice River in Baška near Frýdek-Místek during the floods in 1960 (Source: Povodí Odry State Enterprise Archives); B - Bridge affected by incision of the Ostravice River channel in Baška near Frýdek-Místek (Photo: V. Škarpich).

\section{Conclusions}

Intensive research was realized to detect how the channel transformation of Czech Carpathian rivers affects fluvial ecosystems and human society [8, 9, 10, 11, 12, 16, 23]. The ecosystem services produced by riverine landscape were significantly degraded. The decline in river habitat and reduction in functional floodplain resulted in significant reductions of associated biodiversity, which include impacts on spatiotemporal heterogeneity, functional processes and species. Also, the transformations of channels increased financial requirements for water treatment, repair of hydraulic structures (weirs, dams) or bridges affected by incision of river channel and undercutting. Future river restoration of Czech Carpathian rivers is necessary to improve the current state. Various legislative measures to stopping of further river systems degradation were established but the one of the biggest problem is the potential for river restoration. It is limited by constraints such as need for flood protection of urban areas, need of water for human society, density of urbanisation, etc. (2017-2019): Risks identification and possibility of support of landscape natural functions in 
landscape protected areas influenced by climate change. Thanks are extended to Aneta Krótka, Radek Dušek, Tomáš Gwóźdź, Zdeněk Kašpárek, Matěj Horáček, Veronika Kapustová, Vladimír Šala for their help with fieldwork and data collection.

\section{References}

1. S.A. Schumm, The Fluvial System (1977)

2. G.J. Brierley, K. Fryirs, Geomorphology and River Management: Applications of the River Styles Framework (2005)

3. M. Church, in T. Burt, R. Allison, The sediment cascade, 242-269 (2010)

4. G.M. Kondolf, Environment. Manag. 21, 533-551 (1997)

5. F. Liébault, H. Piégay, Geomorphology 36, 167-186 (2001)

6. B. Wyżga, Regul. Riv.: Res. \& Manag. 17, 85-100 (2001)

7. K. Fryirs, G.J. Brierley, N.J. Preston, M. Kasai, Catena 70, 49-67 (2007)

8. T. Galia, V. Škarpich, Z. Přibyla, J. Hradecký, Geomorphology 253, 305-317 (2016)

9. V. Škarpich, J. Hradecký, R. Dušek, Catena 111, 25-40 (2013)

10. V. Škarpich, Z. Kašpárek, T. Galia, J. Hradecký, Geografie 121, 99-120 (2016)

11. V. Škarpich, T. Galia, J. Hradecký, Zeitschrift für Geomorphologie 60(4), 327-341 (2016)

12. V. Škarpich, M. Horáček, T. Galia, V. Kapustová, V. Šala, Mor. Geogr. Reports 24(2), 24-31 (2016)

13. C.E. Shannon, W. Weaver, The Mathematical Theory of Communication (1949)

14. E.H. Simpson, Nature 163, 688 (1949)

15. O. Brosch, Povodí Odry (2005)

16. S. Lusk, K. Halačka, V. Lusková, Czech Journal of Animal Science 43, 531-536 (1998)

17. K. Chobot, M. Němec, Red List of threatened species of the Czech Republic Vertebrates (2017)

18. M.W. Hardisty, I. C. Potter, The biology of lampreys (1972)

19. L. Augustýn, A. Witkowsko, P. Epler, Acta Sci. Pol. Piscaria 4(1-2), 17-24 (2005)

20. T.N. Pearsons, H.W. Li, G.A. Lamberti, Transactions of the American Fisheries Society 121, 427-436 (1992)

21. R.E. Grift, A.D. Buijse, W.L.T. Van Dense, A.A.M. Machiels, J. Kranenbarg, J.G.P. Klein Breteler, J.J.G.M. Backx, Riv. Res. and Appl. 19, 353-374 (2003)

22. J.A. Deboer, S.A. Ogren, J.M. Holtgren, E.B. Snyder, The American Midland Naturalist 166, 446-452 (2011)

23. J. Hradecký, V. Škarpich, T. Galia, R. Dušek, Vodní hospodářství 62(12) 398-400 (2012) 